\title{
Effects on detoxification enzymes of Helicoverpa armigera (Lepidoptera: Noctuidae) infected by Beauveria bassiana spores and detection of its infection by PCR
}

\author{
Wanida Petlamull $^{\mathrm{a}, *}$, Sawai Boukaew ${ }^{\mathrm{a}}$, Caroline Hauxwell ${ }^{\mathrm{b}}$, Poonsuk Prasertsan ${ }^{\mathrm{c}}$ \\ a College of Innovation and Management, Songkhla Rajabhat University, Songkhla, Thailand \\ b Earth Environmental and Biological Sciences, Bioscience, Faculty of Science and Engineering, \\ Queensland University of Technology, Brisbane, Queensland, Australia \\ c Research and Development Office, Prince of Songkla University, Hat Yai, Songkhla, Thailand
}

*Corresponding author, e-mail: wanida.pe@skru.ac.th

\begin{abstract}
This research aimed to investigate virulence of Beauveria bassiana 36 and its pathogenicity on the infected larvae of Helicoverpa armigera. The virulence was measured by $\mathrm{LD}_{50}$ values and pathogenicity was monitored from detoxification enzymatic changes and pathogenic detection using polymerase chain reaction (PCR). $\mathrm{LD}_{50}$ of B. bassiana against $H$. armigera larvae was highly effective at a very low dose of $7.2 \times 10^{8} \mathrm{spores} / \mathrm{ml}$. Phenoloxidase (PO), glutathione S-transferase (GST), esterase (EST), and glucose oxidase (GOX) activities were found from the hemolymph of the infected $H$. armigera larvae. PO and GST activities from the infected larval sample increased from $53.72 \pm 1.10$ to $79.03 \pm 1.22 \mathrm{U} / \mathrm{mg}$ protein and from $3.81 \pm 0.17$ to $5.77 \pm 0.09 \mathrm{U} / \mathrm{mg}$ protein, respectively, from $0-48 \mathrm{~h}$ and then decreased from $61.75 \pm 1.12$ to $37.46 \pm 1.06 \mathrm{U} / \mathrm{mg}$ protein and from $4.45 \pm 0.09$ to $2.61 \pm 0.12 \mathrm{U} / \mathrm{mg}$ protein from $72-120 \mathrm{~h}$, respectively. EST and GOX activities from the infected larval sample increased from $10.24 \pm 0.44$ to $21.84 \pm 0.64 \mathrm{U} / \mathrm{mg}$ protein and from $3.38 \pm 0.30$ to $10.76 \pm 0.34 \mathrm{U} / \mathrm{mg}$ protein, respectively, from $0-72 \mathrm{~h}$, but decreased slightly from $21.72 \pm 0.76$ to $16.00 \pm 0.89 \mathrm{U} / \mathrm{mg}$ protein and from $4.33 \pm 0.55$ to $4.02 \pm 0.41 \mathrm{U} / \mathrm{mg}$ protein from $96-$ $120 \mathrm{~h}$, respectively. The presence of $B$. bassiana in the infected larvae was detected at post-inoculation using PCR with the specific primers (P1-P3). B. bassiana was successfully and rapidly detected and identified within $72-120 \mathrm{~h}$ with molecular techniques.
\end{abstract}

KEYWORDS: Beauveria bassiana, detoxification enzyme, Helicoverpa armigera, lethal dose, polymerase chain reaction

\section{INTRODUCTION}

Helicoverpa armigera (Lepidoptera, Noctuidae) has been recorded as the most serious pest of 181 plant species belonging to 45 families ${ }^{1}$ with an annual damage cost estimated at over 5 billion US dollars. It has developed resistance up to $54 \%$ of chemical insecticides including pyrethroid, cyclodiene, organophosphate, and carbamates ${ }^{2}$. Integrated control is thought to be an effective alternative control. Beauveria bassiana is an entomopathogenic fungus that causes a natural mortality on insects that is environmentally safe. Therefore, there is worldwide interest in using $B$. bassiana for integrated pest management. After the fungal spores attach to the insect's cuticle, germ tubes develop and penetrate into the cuticle and form blastospores in the hemocoel. Host death is often due to a combination of the action of fungal toxin, the physical obstruction of blood circulation, nutrient depletion, and invasion of the organs ${ }^{3}$. In an attempt to resist the fungus, the immune system of the insect attempts to resist the fungus using the innate immunity by forming a cuticle or peritrophic envelope and using the mechanisms of cellular immunity that include encapsulation, phagocytosis, antimicrobial peptides, and detoxification enzymes. The detoxification enzymes include the main enzymes such as esterase (EST), glutathione S-transferase (GST), and phenoloxidase (PO) ${ }^{4}$. These are the most common enzymes involved in detoxification of xenobiotics and increase in activity of these enzymes is the key mechanism of insect resistance to insecticides ${ }^{5}$. It is known that the attack process of a fungus on an 
insect involves both direct infection and the action of its secondary metabolites that are toxic to the insect ${ }^{6}$. The change in their activities is reflected not only in insect resistance but also to their host plant adaptation as well as in metamorphosis and development ${ }^{7,8}$. In this present study, the glucose oxidase (GOX) enzyme was also analyzed as one parameter of social immunity because this enzyme may act as an antimicrobial agent against insect pathogens ${ }^{9}$. GOX catalyzes the oxidation of $\beta$-Dglucose to D-gluconic acid and hydrogen peroxide that are positively correlated with the inhibition of pathogen development ${ }^{10,11}$. Few reports are available on the change in the activities of all four detoxification enzymes of $H$. armigera when infected by B. bassiana. In order to develop pest management strategies of $H$. armigera, knowledge is needed on the basic mechanisms of the secondary metabolites of this pest infected by $B$. bassiana. Therefore, we attempted to detect the possible relationships between the natural levels of PO, EST, GST, and GOX activities in $H$. armigera and the insect's tolerance to B. bassiana. Moreover, we show that the polymerase chain reaction (PCR) can characterize and detect an insect pathogen that allows identification of Beauveria spp. or B. bassiana isolates as monitoring systems.

\section{MATERIALS AND METHODS}

\section{Fungal spore}

B. bassiana strain 36 was cultured on malt extract agar ( $2 \%$ malt extract, $2 \%$ glucose, $0.1 \%$ peptone, and $2 \%$ agar, all $\%$ in $\mathrm{w} / \mathrm{v}$ ) plates at room temperature for 7-10 days. The fungal spores were collected using a funnel and stored in vials. All experiments were performed at the Laboratory of Earth, Environmental and Biological Sciences, Bioscience, Faculty of Science and Engineering, Queensland University of Technology, Australia.

\section{Ingredients of $H$. armigera's diet}

The composition of the diet for H. armigera is shown in Table 1. The wet and dry ingredients of the diet were weighed and kept separately. The agar was suspended in $1.0 \mathrm{l}$ of water and boiled. The mixture was allowed to cool to just below $60^{\circ} \mathrm{C}$ with frequent mixing to avoid lumping. Once the mix had cooled to below $60^{\circ} \mathrm{C}$, anti-bacterial and anti-fungal agents were added to the mixture with thorough mixing (modified from Ref. 12).
Table 1 Ingredients of diets for rearing $H$. armigera.

\begin{tabular}{ll}
\hline Ingredients & $1000 \mathrm{ml}$ \\
\hline Wheat germ & $75.00 \mathrm{~g}$ \\
Yeast & $62.50 \mathrm{~g}$ \\
Soy flour & $85.00 \mathrm{~g}$ \\
Boiled water & $600 \mathrm{ml}$ \\
Agar & $12.50 \mathrm{~g}+300 \mathrm{ml}$ hot tap water \\
Nipagin & $3.75 \mathrm{~g}$ \\
Sorbic acid & $1.25 \mathrm{~g}$ \\
Vitamin C & $3.75 \mathrm{~g}$ \\
Hydrochloric acid & $0.60 \mathrm{ml}$ \\
\hline
\end{tabular}

\section{Insect}

$H$. armigera larvae were individually reared in 29.5$\mathrm{ml}$ plastic cups containing the prepared diet as a food source. The larvae were then put in trays and kept in a chamber at $25^{\circ} \mathrm{C}$ and $70 \%$ RH until pupation. The pupae were sterilized with $0.025 \%(\mathrm{v} / \mathrm{v})$ bleach for $5 \mathrm{~min}$ and they were then transferred to new containers and kept in buckets containing a $10 \%(\mathrm{v} / \mathrm{v})$ honey solution as the food source. After the individual adults emerged, they were fed with $10 \%$ honey solution. The female adults laid their eggs on a layer of cloth $(15 \times 30 \mathrm{~cm})$. The eggs were sterilized with $0.025 \%$ bleach for $8 \mathrm{~min}$. All of the liquid was removed using a Buchner funnel with filter paper connected to a vacuum pump. The eggs were then placed into a plastic bag and secured with a rubber band until they hatched. After the eggs hatched as $\mathrm{F}_{1}$ larvae, the larvae of 3rd instar (10 days old) were used for all experiments ${ }^{13}$.

\section{Bioassay test}

The spore suspension of $B$. bassiana strain 36 was obtained by $0.05 \%$ Tween $80(\mathrm{v} / \mathrm{v})$ adding sterile distilled water and then mixed thoroughly using a vortex mixer and diluted to obtain a suspension of $10^{5}-10^{10}$ spores $/ \mathrm{ml}$ for the bioassay test compared with a control. The larvae samples (315 samples: 15 samples per replication, 3 replications) of 3rd instar (10 days old) of $H$. armigera were dipped for $5 \mathrm{~s}$ in the spore suspension described above. The controls were maintained by applying $0.05 \%$ Tween 80 and then kept in 29.5-ml plastic cups containing the diet as a food source in the chamber at $25^{\circ} \mathrm{C}$ and $70 \%$ RH. Mortality was measured and recorded until surviving larvae in each treatment had either pupated or were in the pre-pupal stage. The highest concentration causing 50\% mortality was prepared as the standard suspension for enzyme assay as well as PCR detection. 
Each larva from non-infected larvae (control) and infected larvae (B. bassiana 36) was observed as live or dead. Thirty larvae that were still alive after inoculation were collected at $0,24,48,72,96$, and $120 \mathrm{~h}$ for enzyme analysis in their hemolymph and detection of the infection using PCR.

\section{Enzyme assays}

The infected larvae were surface-sterilized with 95\% ethanol and rinsed twice in sterile distilled water. The cleaned larvae were individually cut at the third proleg with a surgical knife. Twenty microliters of hemolymph were collected into the tip of a pipette. The hemolymph collections were centrifuged at $10000 \times g$ for $15 \mathrm{~min}$ at $4^{\circ} \mathrm{C}$ and the supernatants were used as the enzyme source. The enzyme source was used to determine the enzyme activities of GST, EST, PO, and the protein content ${ }^{14}$. The heads of the individual larvae were separated and ground with phosphate buffer $\mathrm{pH} 7.0$ for GOX analysis. The whole body of larvae was stored at $-20^{\circ} \mathrm{C}$ for DNA extraction. All 4 enzyme tests were done with 3 replications.

GST was determined using 1-chloro 2,4dinitrobenzene (CDNB) as the substrate ${ }^{15}$. The assay mixture consisted of $50 \mathrm{mM}$ CDNB in $95 \%$ ethanol, $50 \mathrm{mM} \mathrm{GSH}$ and 10-20 $\mu \mathrm{g}$ of enzyme sample in $3 \mathrm{ml}$ of $50 \mathrm{mM}$ phosphate buffer (pH 7.5). Enzyme activity is expressed in absorbance units at $340 \mathrm{~nm}$.

Esterase activity in the samples was determined spectrophotometrically with minor modifications ${ }^{16}$. The incubation mixture contained $1 \mathrm{ml}$ of $0.54 \mathrm{mM}$ 1-naphthyl acetate in phosphate buffer and $20 \mu \mathrm{l}$ of the sample. The concentration of 1-naphthyl produced during the reaction was measured spectrophotometrically by absorbance at $620 \mathrm{~nm}$.

Phenoloxidase activity was measured using $5 \mu \mathrm{l}$ of fresh whole hemolymph dropped into $95 \mu \mathrm{l}$ of phosphate buffer ( $\mathrm{pH}$ 6.9). After centrifugation $\left(10000 \times g\right.$, at $4^{\circ} \mathrm{C}$ for $\left.5 \mathrm{~min}\right), 40 \mu \mathrm{l}$ of the supernatant was pipetted into a well of a microtiter plate and $160 \mu \mathrm{l}$ of dopamine $(3 \mathrm{mg} / \mathrm{ml}$ phosphate buffer) added as substrate (instead of the L-dopa used previously) because of its high solubility in aqueous media. Phenoloxidase activity was assessed by determining the initial linear increase in absorbance at $492 \mathrm{~nm}$ over $30 \mathrm{~min}$ using a Lab systems Multiskan Bichromatic plate reader. Enzyme activity is expressed in absorbance units at $492 \mathrm{~nm}^{17}$.

GOX activity was determined by measuring the change in absorbance of the reaction mixture at
$460 \mathrm{~nm}$ on a spectrophotometer. The reaction mixture contained $1.0 \mathrm{ml}$ of $0.31 \mathrm{mM}$ o-dianisidine in $1.5 \mathrm{ml}$ of $0.1 \mathrm{M}$ citrate sodium phosphate $(\mathrm{pH}$ 4.5), $0.3 \mathrm{ml}$ of $1.0 \mathrm{M} \mathrm{D}$-glucose, $0.1 \mathrm{ml}$ of $2.0 \mathrm{mg} / \mathrm{ml}$ horse radish peroxidase ${ }^{18}$ and $0.1 \mathrm{ml}$ of the sample.

Protein concentration in the samples was determined using bovine serum albumin as standard to make a calibration curve ${ }^{19}$.

\section{DNA extraction}

The individual larva that showed the highest enzyme activities of each enzyme in their hemolymph was selected to be representative of the whole body to detect the infection using PCR. Four whole bodies of larvae from each time point $(0-120 \mathrm{~h})$ were selected from individual larvae that showed the highest enzyme activity. The DNA extraction was done from the whole body of larvae using the DNeasy Plant Mini Kit (QIAGEN) according to the manufacturer's recommendations. The extracted DNA was stored at $-20^{\circ} \mathrm{C}$ until use.

\section{PCR detection of fungus within the infected larvae of $H$. armigera}

The B. bassiana-specific primers used for detection of $B$. bassiana amplification within the infected larvae of $H$. armigera were P1 (5'AAGCTTCGACATGGTCTG) and P3 $\left(5^{\prime}\right.$ GGAGGTGGTGAGGTTCTGTT) ${ }^{20}$. PCR reactions were performed in a final volume of $25 \mu \mathrm{l}$, containing $5 \mu \mathrm{l}$ of $5 \mathrm{X}$ buffer, $1 \mu \mathrm{l}$ of $25 \mathrm{mM} \mathrm{MgCl}{ }_{2}$, $200 \mu \mathrm{M}$ dNTPs mix, $0.4 \mathrm{mM}$ of each primer, $1 \mathrm{U}$ of Taq DNA polymerase, and $1 \mu l$ of DNA template. PCR condition were as follow: initial denaturation at $94^{\circ} \mathrm{C}$ for $5 \mathrm{~min}, 35$ cycles at $94^{\circ} \mathrm{C}$ for $30 \mathrm{~s}, 53^{\circ} \mathrm{C}$ for $30 \mathrm{~s}$ and $72^{\circ} \mathrm{C}$ for $1 \mathrm{~min}$, and final extension at $72^{\circ} \mathrm{C}$ for $10 \mathrm{~min}$. PCRs were analyzed on gels.

\section{Statistical analysis}

The median lethal insecticide dose $\left(\mathrm{LD}_{50}\right)$ that killed $50 \%$ of the insects was determined by probit analysis. Enzyme activities were compared by one-way analysis of variance (ANOVA) followed by Tukey's studentized test. The enzyme responses obtained are presented as mean and standard error (SE). The level of significance was taken as $p \leqslant 0.001$ and all tests were undertaken using Genstat.

\section{RESULTS AND DISCUSSION}

\section{Bioassay}

After the 3rd instar $H$. armigera larvae were inoculated by serial concentrations $\left(10^{5}, 10^{6}, 10^{7}, 10^{8}\right.$, 


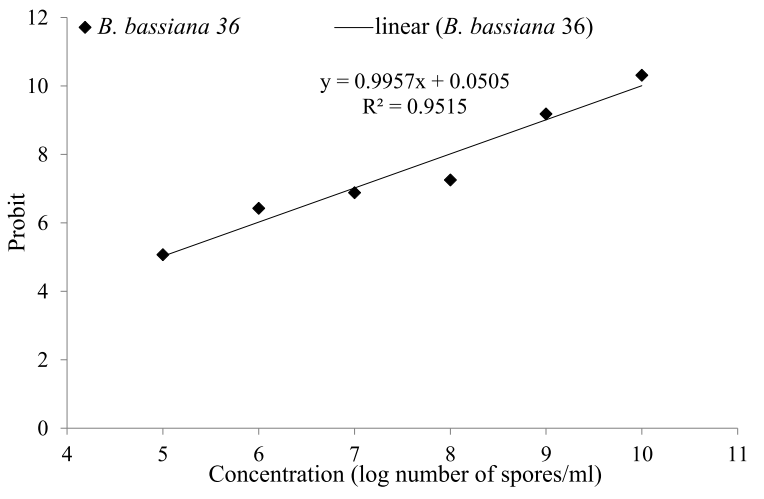

Fig. 1 Effect of B. bassiana on larvae of $H$. armigera, death-rate is converted to probit.

$10^{9}$, and $10^{10}$ spores $/ \mathrm{ml}$ ) of the fungus $B$. bassiana. The mortality was observed as a linear relationship between probit mortality and dose concentration. $H$. armigera larvae mortality due to spore concentration was different among all concentrations and varied from 5.07-10.31 probits. These results showed that there was a correlation between increasing spore and enhancement of mortality in $\mathrm{H}$. armigera larvae (Fig. 1). The analysis of variance results showed significant differences in the mortality of $H$. armigera larvae treated with spores analyzed by line regression analysis (Fig. 1). Treatment of the larvae using the highest spore concentration of $10^{10}$ spores $/ \mathrm{ml}$ resulted in complete mortality (100\%). $\mathrm{LD}_{50}$ (the effective concentration of fungal spore or $50 \%$ mortality, calculated by bioassay tests) was at a concentration of $7.2 \times 10^{8}$ spores $/ \mathrm{ml}$ after 5 days post-inoculation. During $0-5$ days postinoculation of 3rd instar larvae of $H$. armigera infected with $B$. bassiana $\left(10^{7}\right.$ spores $\left./ \mathrm{ml}\right)$, Ref. 21 reported larval mortality ranged from $29.69-41.89 \%$. The percentage mortality in our experiment was slightly higher than Ref. 21. This was possibly due to a higher dose inoculation. Earlier study reported that $84 \%$ mortality in 3rd instar larvae of $H$. armigera when sprayed with $B$. bassiana at $10^{5}$ spores $/ \mathrm{ml}^{22}$. So, the isolates of different fungi could result in different rates of pathogenicity.

Observations of the host defensive reaction were conducted after two days post-inoculation. Response to the fungal attack showed dark spots of various shapes and sizes that appeared on the cuticle surface of the infected larvae. The larvae died after developing various morphological deformities. These abnormalities ranged from blackening of the infected skin which formed a fragile skin that

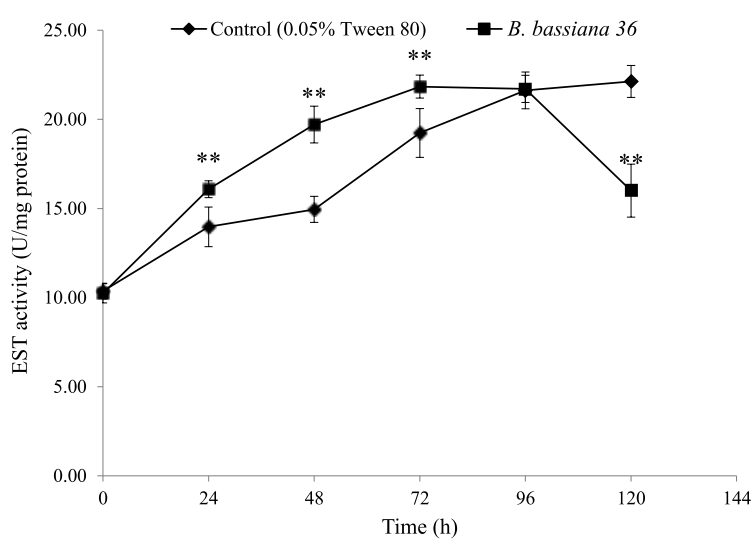

Fig. 2 EST activity (U/mg) affected by $B$. bassiana strain 36 , bar represents mean $\pm \operatorname{SE}(n=30)$ and ** shows significant differences in activities versus control $(p<0.001)$.

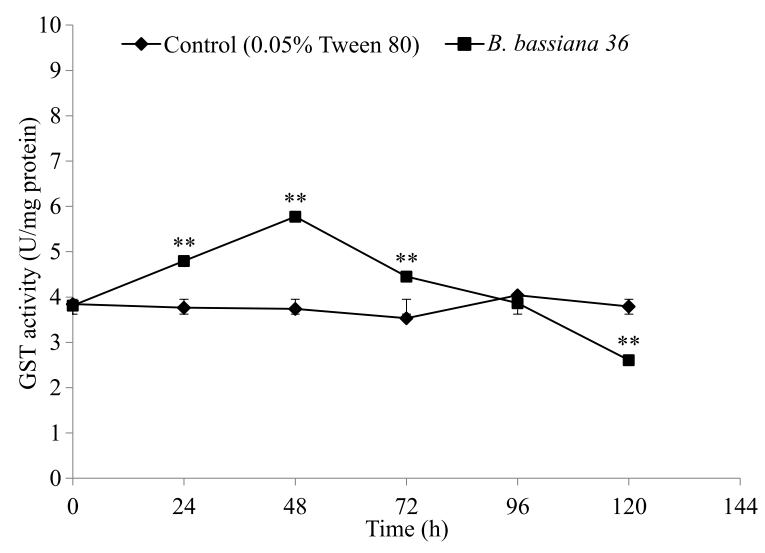

Fig. 3 GST activity (U/mg) affected by $B$. bassiana strain 36 , bar represents mean $\pm \operatorname{SE}(n=30)$ and $* *$ shows significant differences in activities versus control $(p<0.001)$.

developed abnormal body parts. The larvae became very weak and their death from mycosis started 3 days after the infection and ended on day 4 or 5 .

\section{Detoxification enzyme activities}

The effects of detoxification on the activities of the enzymes (EST, GST, PO) of $H$. armigera larvae infected with fungal spores of $B$. bassiana are shown in Figs. 2-4. Most of the enzyme activities were significantly higher than the control during the 24$72 \mathrm{~h}$ post-inoculation period.

The EST activity in the hemolymph of the $H$. armigera larvae treated with fungal spores was significantly induced. The EST activities of the infected larvae at $24 \mathrm{~h}(F=91.7 ; \mathrm{df}=59 ; p<0.001)$, 


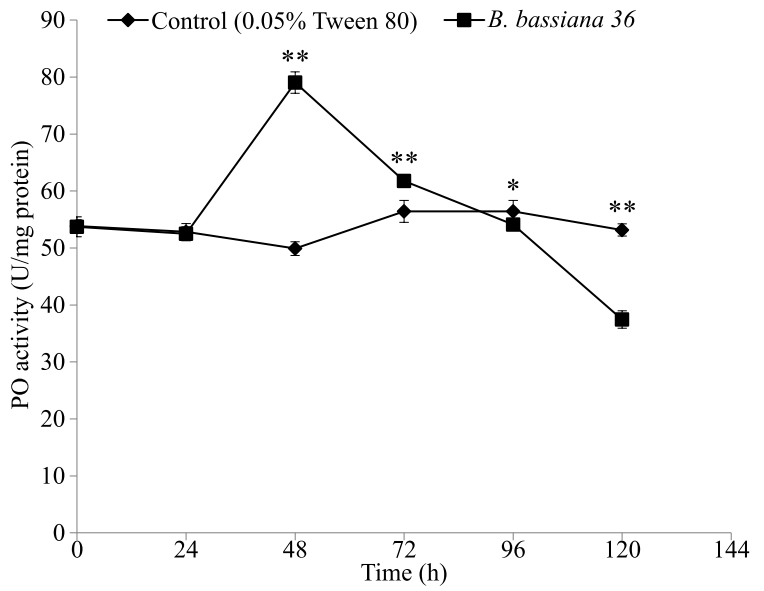

Fig. 4 PO activity (U/mg) affected by B. bassiana strain 36 , bar represents mean \pm SE $(n=30)$ and asterisks show significant differences in activities versus control (**, $p<$ 0.001 and $*, p<0.005)$.

$48 \mathrm{~h}(F=425.3 ; \mathrm{df}=59 ; p<0.001)$, and $72 \mathrm{~h}$ ( $F=88.4 ; \mathrm{df}=59 ; p<0.001)$ were significantly higher than the control (Fig. 2). The highest activity was observed at $72 \mathrm{~h}$ post-inoculation $(21.84 \mathrm{U} / \mathrm{mg}$ protein) and then it decreased. At $120 \mathrm{~h}$ postinoculation, the EST activity was significantly lower than the control $(F=371.6 ; \mathrm{df}=59 ; p<0.001)$. The activity of nonspecific esterase increased due to induction of additional isoenzymes ${ }^{23}$.

Similar results of GST activity were obtained from $H$. armigera larvae after treatment with fungal spores after 0-48 h. GST activities of infected larvae at $24 \mathrm{~h}(F=400.8 ; \mathrm{df}=59 ; p<0.001)$ and $48 \mathrm{~h}$ $(F=1416 ; \mathrm{df}=59 ; p<0.001)$ post-inoculation were significantly higher than the control. The highest activity was observed at $48 \mathrm{~h}(5.77 \mathrm{U} / \mathrm{mg}$ protein) post-inoculation (Fig. 3). The highest PO activity of the infected larvae was $79.03 \mathrm{U} / \mathrm{mg}$ protein observed at $48 \mathrm{~h}$ post-inoculation and was significantly higher than the control $(F=1718$; df $=59 ; p<0.001$ ) (Fig. 4).

Apparently, the enhanced levels of the detoxification enzymes resulted from defense mechanisms against the xenobiotics in response to the intoxication due to metabolites of the pathogen or the products of host tissue degradation. GST activity in insects was found to increase the resistant to insecticides ${ }^{24}$.

GST also takes part in the removal of metabolites and the protection of tissues from damage by free radicals ${ }^{25}$. Moreover, GST was found to participate in metabolism and detoxification of or-

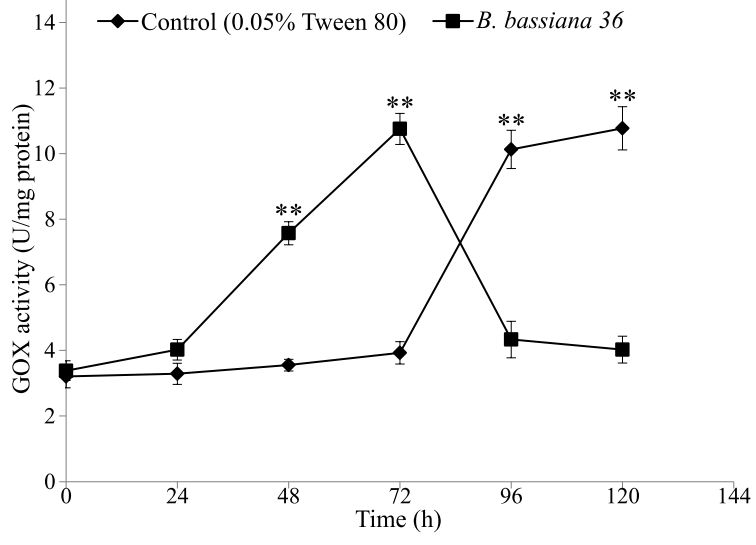

Fig. 5 GOX activity (U/mg) affected by $B$. bassiana strain 36 , bar represent mean \pm SE $(n=30)$ and ** shows significant differences in activities versus control $(p<0.001)$.

ganic phosphates, pyrethroids, carbamates, and juvenoids ${ }^{26}$. PO is the key enzyme in the developmental process of insects. $\mathrm{PO}$ is responsible for catalyzing the hydroxylation of monophenols and oxidation of o-diphenols ${ }^{27}$, that can spontaneously polymerize to form melanins which are involved in cuticle sclerotization and melanization associated with nodulation, encapsulation, and wound healing. Furthermore, PO might provide cytotoxic quinonoid compounds to kill the opportunistically invading microorganism at this site ${ }^{28}$.

The main factor that increases the activity of detoxification enzymes may be the mechanical damage to the insect's cuticle by hyphae due to the penetration and action of fungal toxins released into the hemocoel ${ }^{7,23}$. Thus, the increase in detoxification enzymes after treatment up to $72 \mathrm{~h}$ suggests that these enzyme activities of $H$. armigera larvae may be directed at elimination of fungal metabolites and toxic substances of $B$. bassiana formed by penetration into the hemocoel. Zibaee et $\mathrm{al}^{5}$ also reported that the effects of fungal spores presented a similar trend of changing secondary metabolites of detoxification enzymes of insects.

GOX activity of $H$. armigera larvae after treatment with fungal spores significantly increased in $H$. armigera larvae and the highest activity (10.76 U/mg protein) was observed at $72 \mathrm{~h}$ postinoculation (Fig. 5), which was significantly higher than the control $(F=1259 ; \mathrm{df}=59 ; \quad p<$ 0.001). GOX plays an important role in the interaction between the Lepidoptera caterpillar and the host plants ${ }^{29,30}$. GOX activities have been detected in insect species such as Spodoptera exigua ${ }^{31}$, 
H. armigera, and $H$. assulta ${ }^{32}$ and recently were extensively investigated in 85 species of Lepidoptera and three species of plant-feeding Hymenoptera ${ }^{30}$. However, few reports showed the secretion of this enzyme in insects infected by entomopathogenic fungi.

GOX activity is essential for the production of antiseptic substances ${ }^{33}$. This enzyme catalyzes the oxidation of glucose into hydrogen peroxide and D-glucono- $\delta$-lactone. GOX is produced by certain species of fungi and insects and displays antibacterial activity when oxygen and glucose are present ${ }^{34}$. Therefore, GOX activity of infected larvae increased rapidly after $24-72 \mathrm{~h}$ post-inoculation, which was higher than the control. It was possible that the enzyme in both the larvae and the fungi was presented to oxidize glucose in artificial diet. The control larvae had slightly increased GOX activity after $72 \mathrm{~h}$ post-inoculation, probably due to their growth and later developmental stage that leads them to increase food demand. Merkx-Jacques and Bede ${ }^{31}$ reported that GOX activity is closely correlated with the amount of time larvae spent feeding on artificial diet. GOX activity increased throughout in the later developmental stage of larvae fed with wheat germ-based artificial diet, whole body GOX of $S$. exigua (Lepidoptera: Noctuidae) larvae in 5th instars reared on a wheat germ-based artificial diet was over five-fold higher than 2nd instars ${ }^{31}$. In addition, diet nutritional composition is a major factor influencing the GOX activity of larvae $H$. armigera $^{35}$. The high level of protein in the artificial diet increased GOX activity. Larvae fed on the 24P:17C diet had twice the GOX activity compared to caterpillars fed on the 25P:39C diet ${ }^{36}$. In this study, larvae 3 rd instars of $H$. armigera were fed on the 28P:12C diet that might induce GOX secretion. However, GOX activity of the infected larvae decreased rapidly after $72 \mathrm{~h}$ post-inoculation which might possibly occur due to the cell death resulting in the loss of all biological activities.

\section{Detection of infection by $B$. bassiana within the larvae of $\boldsymbol{H}$. armigera}

The ability of the PCR-based system to identify $B$. bassiana infected larvae of $H$. armigera was determined by a comparison with the non-infected larvae (control). An analysis of these results indicated that the PCR product was formed with the extracted DNA at several times after treatment with the P1P3 primer sets (Fig. 6). Additionally, a product was observed from total DNA from larvae that had been infected with $B$. bassiana and incubated at least 10
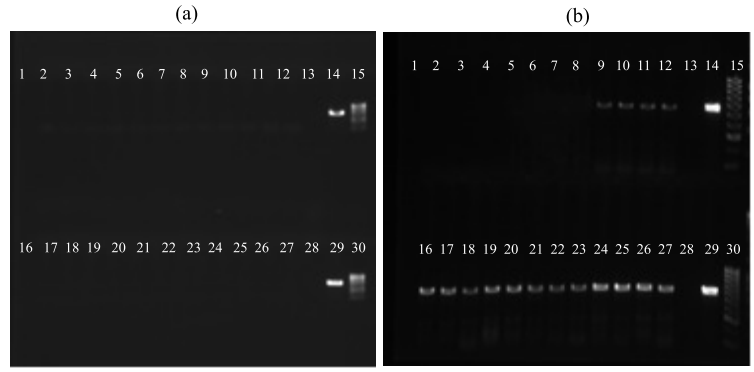

Fig. 6 Gel red agarose gel of P1-P3 PCR products from (a) non-infected larvae of $H$. armigera and (b) infectedlarvae of $H$. armigera by $B$. bassiana strain 36 after 0 $120 \mathrm{~h}$ post inoculation. At $0 \mathrm{~h}$, lanes $1-4 ; 24 \mathrm{~h}$, lanes 5-8; 48 h, lanes 9-12; lanes 13 and 28, negative PCR product; lanes 14 and 29, positive PCR product; lanes 15 and 30, HyperLadder $1000 \mathrm{~kb}$; $72 \mathrm{~h}$, lanes 16-19; $96 \mathrm{~h}$, lanes 20-23; $120 \mathrm{~h}$, lanes 24-27.

days ${ }^{20}$.

This study proposes to apply the detoxification enzyme to support the investigation on inhibitors of detoxification enzymes. On other hand, ways to block or suppress the activity of insect defense systems would increase their susceptibility to entomopathogenic fungi used for biocontrol. Probably this application could successfully increase the biological control efficiency from biological products as entomopathogenic fungi after combination between biological products and inhibitors of detoxification enzymes.

Insects have efficient immune systems that are able to withstand challenges from the majority of microorganisms present in the different habitats where they live. The innate immune system of insects is highly developed and it relies on humoral and cellular components ${ }^{37}$. Circulating hemocytes have important roles in the immune mechanisms of insects against microorganisms ${ }^{38}$. The ability of the fungus to infect an insect depends on its ability to adhere and penetrate the exoskeleton, resist the insect's hemolymph-borne defenses, and grow rapidly. The spore adheres to the cuticle and germinates for penetration through the exoskeleton with a combination of mechanical pressure and lytic enzymes. Following penetration into the hemolymph, the fungus grows as a yeast-like blastospore from the vegetative hyphae. Insect defense includes encapsulation of the fungus by granulocytes and plasmatocytes and formation of a nodule that may be melanized ${ }^{39}$.

Acknowledgements: The authors would like to thank 
Songkhla Rajabhat University, Thailand Research Fund (RTA5780002) for their financial support and Research Unit of Agricultural Innovation and Smart System for their experimental material support of this research work.

\section{REFERENCES}

1. Srivastava CP, Ahmad R, Ujagir R, Das SB (2005) Helicoverpa armigera hubner management in pulses present scenario and future strategies. In: Sexena $\mathrm{H}$, Rai AB, Ahamad R, Gupta S (eds) Recent Advances in Helicoverpa armigera Management, Indian Society of Pulses Research and Development, Kanpur, India, pp 265-286.

2. Ahmad R, Saxena H, Rai AB, Singh SK (2005) Resurgence and resistance of Helicoverpa armigera in India. In: Sexena H, Rai AB, Ahamad R, Gupta S (eds) Recent Advances in Helicoverpa armigera Management, Indian Society of Pulses Research and Development, Kanpur, India, pp 48-64.

3. Fan J, Xie Y, Xue J, Liu R (2013) The effect of Beauveria brongniartii and its secondary metabolites on the detoxification enzymes of the pine caterpillar, Dendrolimus tabulaeformis. J Insect Sci 13, ID 44.

4. Li X, Schuler MA, Berenbaum MR (2007) Molecular mechanisms of metabolic resistance to synthetic and natural xenobiotics. Annu Rev Entomol 52, 231-253.

5. Zibaee A, Bandani AR, Tork M (2009) Effect of the entomopathogenic fungus, Beauveria bassiana, and its secondary metabolite on detoxifying enzyme activities and acetylcholinesterase (AChE) of the Sunn pest, Eurygaster integriceps (Heteroptera: scutellaridae). Biocontrol Sci Technol 19, 485-498.

6. Xia Y, Clarkson JM, Charnley AK (2001) Acid phosphatases of Metarhizium anisopliae during infection of the tobacco hornworm Manduca sexta. Arch Microbiol 176, 427-434.

7. Serebrov VV, Gerber ON, Malyarchuk AA, Martemyanov VV, Alekseev AA, Glupov VV (2006) Effect of entomopathogenicfungi on detoxification enzyme activity in greater wax moth Galleria mellonella L. (Lepidoptera, Pyralidae) and role of detoxification enzymes in development of insect resistance to entomopathogenic fungi. Biol Bull 33, ID 581.

8. Zibaee A, Bandani AR, Talaei-Hassanlouei R, Malagoli D (2011) Cellular immune reactions of the sunn pest, Eurygaster integriceps, to the entomopathogenic fungus, Beauveria bassiana and its secondary metabolites. J Insect Sci 11, ID 138.

9. Musser RO, Hum-Musser SM, Eichenseer H, Peiffer M, Ervin G, Murphy JB, Felton GW (2002) Caterpillar saliva beats plant defenses. Nature 416, 599-600.

10. Taormina PJ, Niemira BA, Beuchat, LR (2001) Inhibitory activity of honey against foodborne pathogens as influenced by the presence of hydrogen peroxide and level of antioxidant power. Int $J$ Food Microbiol 69, 217-225.
11. Brudzynski K (2006) Effect of hydrogen peroxide on anti- bacterial activities of Canadian honeys. Can $J$ Microbiol 52, 1228-1237.

12. Griffith JSR, Haskell PT (1988) Culture of Heliothis armigera (Lepidoptera: Noctuidae) using novel group rearing techniques and a semi-artificial diet. Trop Pest Manag 34, 349-355.

13. Grzywacz D, Rabindra RJ, Brown M, Jones KA, Parnell M (2011) Insect culture for virus production and testing. In: The Helicoverpa armigera NPV Production Manual, FAO, pp 15-29.

14. Dubovskiy IM, Slyamova ND, Kryukov VY, Yaroslavtseva ON, Levchenko MV, Belgibaeva AB, Adilkhankyzy AA, Glupov VV (2012) The activity of nonspecific esterase and glutathione-S-transferase in Locust amigratoria larvae infected with the fungus Metarhizium anisopliae (Ascomycota, Hypocreales). Entomol Rev 92, 27-31.

15. Kao CH, Hung CF, Sun CN (1989) Parathion and methyl parathion resistance in diamondback moth (Lepidoptera: Plutellidae) larvae. J Econ Entomol 82, 1299-1304.

16. Asperen van K (1962) A study of housefly esterases by means of a sensitive colorimetric method. $J$ Insect Physiol 8, 401-416.

17. Goldsworthy G, Opoku-ware K, Mullen L (2002) Adipokinetic hormone enhances laminarin and bacterial lipopolysaccharide induced activation of the prophenoloxidase cascade in the African migratory locust, Locusta migratoria. J Insect Physiol 48, 601-608.

18. Kelley RL, Adinarayana Reddy C (1986) Purification and characterization of glucose oxidase from ligninolytic cultures of Phanerohaete chrysosporium. $J$ Bacteriol 166, 269-274.

19. Bradford MM (1976) A rapid and sensitive method for the quantitation of microgram quantities of protein utilizing the principle of protein-dye binding. Anal Biochem 72, 248-254.

20. Hegedus DD, Khachatourians GG (1996) Identification and differentiation of the entomopathogenic dungus Beauveria bassiana using polymerase chain reaction and single-strand conformation polymorphism analysis. J Invertebr Pathol 67, 289-299.

21. Rijal JP, Dhoj YGC, Thapa RB, Kafle L (2008) Virulence of native isolates of Metarhizium anisopliae and Beauveria bassiana against Helicoverpa armigera in Nepal. Form Entomol 28, 21-29.

22. Sandhu SS, Unkles SE, Rajak RC, Kinghorn JR (2001) Generation of benomyl resistant Beauveria bassiana strains and their infectivity against Helicoverpa armigera. Biocontrol Sci Technol 11, 245-250.

23. Serebrov VV, Alekseev AA, Glupov VV (2001) Changes in the activity and range of esterases in the haemolymph of the larvae of the greater wax moth Galleria mellonella L. (Lepidoptera: Pyralidae) during mycoses. Izv Akad Nauk Ser Biol 5, 588-592. 
24. Papadopopoulos AL, Boukouvala E, Kakaliouras G, Kostaropoulos J, Papadopoulou-Mourkidou E (2000) Effect of organophosphate and pyrethroid insecticides on the expression of GSTs from Tenebrio molitor pupae. Pestic Biochem Physiol 68, 26-33.

25. Bakanova EI, Eremina OY, Roslavtseva SA (1992) The properties and functions of glutathione-stransferase in Arthropods. Izv Akad Nauk Ser Biol 4, 537-545.

26. Pasteur N, Nance E, Bons N (2001) Tissue localization of overproduced esterases in the mosquito Culex pipiens (Diptera: Culicidae). J Med Entomol 38, 791-801.

27. Wang XB, Ma CX, He KQ, Si HQ, Zhang YL (2008) Development and application of a STS marker for kernel PPO gene located on chromosome 2D in common wheat. Sci Agric 39, 1583-1590.

28. Nappi AJ, Christensen BM (2005) Melanogenesis and associated cytotoxic reactions: applications to insect innate immunity. Insect Biochem Mol Biol 35, 443-459.

29. Peiffer M, Felton GW (2005) The host plant as a factor in the synthesis and secretion of salivary glucose oxidase in larval Helicoverpa zea. Arch Insect Biochem Physiol 58, 106-113.

30. Eichenseer H, Mathews MC, Powell JS, Felton GW (2010) Survey of a salivary effector in caterpillars:glucose oxidase variation and correlation with host range. $J$ Chem Ecol 36, 885-897.

31. Merkx-Jacques M, Bede JC (2005) Influence of diet on the larval beet armyworm, Spodoptera exigua, glucose oxidase activity. $J$ Insect Sci 5, ID 48.
32. Zong N, Wang CZ (2004) Induction of nicotine in tobacco by herbivory and its relation to glucose oxidase activity in the labial gland of three noctuid caterpillars. Chin Sci Bull 49, 1596-1601.

33. Sano O, Kunikata T, Kohno K, Iwaki K, Ikeda M, Kurimoto M (2004) Characterization of royal jelly proteins in both Africanized and European honeybees (Apis mellifera) by two dimensional gel electrophoresis. J Agr Food Chem 52, 15-20.

34. Alaux C, et al (2010) Interactions between Nosema microspores and a neonicotinoid weaken honeybees (Apis mellifera). Environ Microbiol 12, 774-782.

35. Babic B, Poisson A, Darwish S, Lacasse J, MerkxJacques M, Despland E, Bede JC (2008) Influence of dietary nutritional composition on caterpillar salivary enzyme activity. $J$ Insect Physiol 54, 286-296.

36. Ji J (2014) Effect of diet on Spodoptera exigua (Hübner) caterpillar enzyme activity. Master thesis, Univ Montreal, Quebec, Canada.

37. Lavine MD, Strand MR (2002) Insect hemocytes and their role in immunity. Insect Biochem Mol Biol 32, 1295-1309.

38. Russo J, Brehelin M, Carton Y (2001) Haemocyte changes in resistant and susceptible strains of $D$. melanogaster caused by virulent and avirulent strains of the parasitic wasp Leptopilina boulardi. $J$ Insect Physiol 47, 167-172.

39. Mullen LM, Goldsworth GJ (2006) Immune responses of locusts to challenge with the pathogenic fungus Metarhizium or high doses of laminarin. $J$ Insect Physiol 52, 389-398. 